\title{
ESTATIZAÇÃO E DESESTATIZAÇÁO NO BRASIL: \\ O PAPEL DAS EMPRESAS ESTATAIS NOS CICLOS DA INTERVENÇÃO GOVERNAMENTAL NO DOMÍNIO ECONÔMICO
}

\author{
Frederico Lustosa Da Costa \\ Universidad Federal Fluminense, Brasil \\ fredlustosa@gmail.com \\ Vítor Yoshihara Miano \\ Universidad Federal Fluminense, Brasil \\ vitormiano@gmail.com
}

\section{RESUMEN}

Este artículo tiene como objetivo presentar los movimientos de expansión y contracción del Sector Productivo Estatal (SPE) brasileño de 1930 a 2010, y también los argumentos utilizados por los gobernantes para justificar estos procesos. Primero, se describe la formación del SPE brasileño, destacando el crecimiento cuantitativo de estas organizaciones. Se analizan los cambios económicos e ideológicos en que se inició el movimiento de privatización de los años ochenta, que tenía como objetivo detener el crecimiento descontrolado del número de empresas estatales. Desde 1990, se produjo una intensificación de lo proceso y, con el inicio del gobierno de Fernando Henrique Cardoso, la privatización se convirtió en parte de un movimiento más amplio para reformar el Estado. La última sección aborda los gobiernos de Lula, que se caracteriza por una recuperación de la intervención estatal y, por otra parte, por lo mantenimiento de la política de concesiones iniciada por el gobierno anterior.

Palabras clave: Empresas públicas, Privatización, Intervención estatal, Brasil. 


\title{
NATIONALIZATION AND PRIVATIZATION IN BRAZIL: THE ROLE OF STATE COMPANIES IN THE CYCLES OF GOVERNMENT INTERVENTION IN THE ECONOMIC FIELD
}

\begin{abstract}
This paper aims to unveil the movements of expansion and shrinkage of the State Productive Sector (SPS) in Brazil between 1930 and 2010, as well as the arguments used by the governments to justify these processes. First, we describe the formation of the Brazilian SPS, highlighting the quantitative growth of these organizations. We analyse the economic and ideological changes triggering the privatization movement of the 80 's, which aimed to stop the uncontrolled growth of the number of state companies. Since 1990, the privatization process intensified and, with the beginning of the government of Fernando Henrique Cardoso, it became part of a broader movement to reform the State. The final section addresses the Lula mandates, characterized by a recovery of State intervention and, on the other hand, by the maintenance of the concessions policy started by the previous government.
\end{abstract}

Keywords: State companies, Privatization, State intervention, Brazil. 


\section{INTRODUÇÃO}

A partir de 1930, o Estado brasileiro assumiu o papel central de indutor do processo de industrialização da economia nacional, contribuindo decisivamente para o desenvolvimento do capitalismo no Brasil. O modelo de substituição de importaçóes utilizado era característico de países capitalistas de desenvolvimento tardio, que ingressaram na era industrial quando as bases técnicas e financeiras das atividades manufatureiras já eram relativamente complexas. E, nesse modelo, as empresas estatais tiveram lugar de destaque, sobretudo a partir dos anos 1940, atuando como diferentes instrumentos de intervenção no campo econômico (Furtado 1979). Nesse contexto, os grandes projetos industriais almejados possuíam forte relação de interdependência, obrigando que sua implantação fosse feita de maneira conjunta, planejada. Coube ao Estado desempenhar a função de condutor dessa estratégia de industrialização, que desde o início esteve associada às empresas estatais (Gobetti 2010).

A partir da década de 1970, o keynesianismo e o modelo de Estado de bem-estar passaram a ser questionados, contribuindo, entre outros fatores, para o início dos movimentos de desestatização. Esse processo, que se iniciou como medida para conter o descontrolado crescimento do aparelho estatal, chegou ao seu ápice durante a reforma administrativa de 1995, que objetivava náo só se desfazer das empresas estatais como reposicionar o Estado, visando a alcançar uma mudança na ordem econômica. No entanto, mais recentemente, uma nova inflexão no histórico brasileiro das empresas estatais e da intervenção estatal ocorreu. Durante os mandatos do presidente Lula, a participação das empresas estatais na execução de políticas públicas foi reforçada e o nível de investimentos aplicados por essas organizações teve grande contribuição macroeconômica. Numericamente, não somente novas subsidiárias paraestatais "bem-sucedidas" foram criadas como também ocorreu uma nova fase de expansão destas organizaçóes, seja na esfera federal, estadual ou municipal. Entretanto, esta retomada da intervenção estatal incorporou as políticas de concessão de serviços e obras públicas iniciadas no governo anterior, combinando o reforço da intervenção direta via investimentos públicos e a transferência de serviços públicos ao setor privado, via concessôes.

O debate entre privatização e estatização envolve uma variedade de aspectos e de posicionamentos. Assim como as correntes econômicas intervencionistas e liberais se alternam como balizadoras das políticas econômicas, as empresas estatais ora são vistas como fomentadoras da economia nacional, ora como um fardo para o orçamento público e uma fonte irremediável de ineficiência macro e microeconômica. 
O presente trabalho apresenta um histórico dos movimentos de estatização e desestatização da economia brasileira, sob a ótica das empresas estatais. O recorte temporal abordado pela pesquisa, de 1930 a 2010, foi dividido de acordo com o tipo e a intensidade dos movimentos predominantes. $\mathrm{Ou}$ seja, foram analisados: o quantitativo de empresas públicas, o crescimento do Setor Produtivo Estatal, as alienaçóes e as motivaçóes que justificavam as açôes tomadas (ou por quê náo foram tomadas). Com isso, procurouse esclarecer as distinçóes entre os períodos de expansão e contração do aparelho estatal, no que diz respeito às empresas públicas. Subsidiariamente, também será discutida a relação destas organizaçóes com o ajuste fiscal do Estado, principalmente a partir da reforma de 1994 e durante os governos Lula, no intuito de fornecer informaçóes acerca dos resultados mais recentes das privatizaçóes e da manutenção (ou expansão) do setor produtivo estatal.

A primeira seção aborda o processo de formação do setor produtivo estatal brasileiro, de grande contribuição para a passagem da economia brasileira de um modelo produtivo baseado essencialmente no setor agroexportador para um modelo urbano-industrial. Foi evidenciado o crescimento quantitativo destas organizaçóes de acordo com o governo vigente, assim como as motivaçóes implícitas que suscitaram a estatização da economia. Percebeu-se a tendência de intervenção do Estado para incitar e dirigir o crescimento da economia, o que refletiu num período de grande expansão do número de estatais. $\mathrm{O}$ segundo capítulo enumera algumas mudanças econômicas e ideológicas que iniciaram o movimento de desestatização brasileiro a partir da década de 1980 e que configuraram o cenário anterior ao governo Fernando Collor em 1990. Este período representa uma desaceleraçáo do crescimento do número de estatais que, no entanto, não representou uma inversão na tendência estatizante, pois a privatização ainda náo havia sido incorporada à agenda política do governo.

O início da terceira seção, relativo ao período de 1990 a 1994, discorre sobre a intensificação dos movimentos de desestatização associados à privatização das empresas industriais, objetivando principalmente reajustes fiscais. São expostos alguns problemas, tanto de ordem política como de ordem técnica, que afetaram negativamente o processo de desestatização neste período, fazendo com que o resultado esperado não fosse alcançado. Com o início do governo de Fernando Henrique Cardoso (FHC), a privatização passou a fazer parte de um movimento mais amplo de reforma do Estado. Durante 1995 e 2002 grandes empresas públicas foram alienadas, iniciaram-se as privatizaçóes estaduais e a transferência de serviços públicos. Uma série de reformas constitucionais e legais ocorreu, 
de forma a permitir e/ou favorecer os processos de desestatização. Novas modalidades como as concessóes, federais e estaduais, representaram mudanças marcantes no cenário econômico nacional.

A última seção aborda a retomada da intervenção econômica estatal, realizada durante os dois governos de Luís Inácio "Lula" da Silva. Neste período, ocorreu uma estabilização nas privatizaçóes e não somente o número de empresas estatais voltou a crescer, como a participação destas organizaçóes na economia foi reforçada. No entanto, ao mesmo tempo em que esta mudança de postura do governo sobre a intervenção estatal acontecia, dava-se continuidade ao regime de concessóes iniciado no governo anterior. Diversas agências reguladoras foram criadas, seja na esfera federal, estadual ou municipal e outras empresas e setores passaram a ser administrados pelo capital privado. $\mathrm{Na}$ conclusão, algumas consideraçôes acerca do tema são apresentadas.

\section{FORMAÇÃO E DESENVOLVIMENTO DO SETOR PRODUTIVO ESTATAL BRASILEIRO - 1930 A 1980}

A consolidação do regime republicano no Brasil, ao final do século XIX e, sobretudo, ao início do século XX, demarcou um período de expansão da intervenção do Estado na economia. $O$ fortalecimento da presença estatal se manifestou, principalmente, na política federal de valorização do café, produto no qual se apoiava grande parte da produçáo nacional. Como um país agroexportador, o Brasil contava com um pequeno número de empresas estatais (14 no total), com destaque para o Banco do Brasil e a Caixa Econômica Federal, organizaçóes que se colocam atualmente como dois dos maiores bancos que operam no país.

No final dos anos 1920, o mundo viveu uma profunda crise econômica, ocasionada pela reduçáo da demanda agregada. A elevaçáo da produtividade industrial náo era acompanhada pela capacidade da população em consumir os bens que a indústria produzia. A pequena depressão econômica, termo eufemístico que pretendia descrever a crise, se converteu na Grande Depressão dos anos 1930. Estabeleceu-se um ciclo vicioso de empobrecimento, provocado pela perda de oportunidades de trabalho durante a depressão industrial. A solução proposta pelo economista inglês John Mayard Keynes foi fazer com que o Estado criasse frentes de serviço para que a população obtivesse novas fontes de renda, podendo assim voltar a consumir. $\mathrm{O}$ sucesso na aplicaçáo dessa proposta nos Estados Unidos, com a realização de milhares de pequenas obras públicas, na era do chamado New Deal, criou um novo paradigma econômico - a ideia de que o Estado poderia intervir no mercado e coordenar decisóes econômicas para promover o crescimento, regulando o emprego e o consumo, e tornando- 
se um grande investidor, comprador e empregador (Gurgel 2003).

Abandonada a convicção na otimização de livres mercados, coube ao Estado executar medidas para interromper o ciclo vicioso que retirava os consumidores do mercado, inibia a produção e aprofundava a crise. Esse papel objetivava garantir o crescimento contínuo do produto, sem os sobressaltos das crises, assegurando o pleno emprego dos fatores de produção e monitorando as propensóes cambiantes a poupar e a consumir (Gurgel 2003). A intervenção econômica do Estado passou a ser considerada virtuosa e, nos países latino-americanos, essa ideia foi levada às últimas consequências no modelo de crescimento baseado na industrialização via substituição de importações. A legitimação pela doutrina keynesiana e a prática de alguns países coincidiu com o auge das ideologias autoritárias e o descrédito relativo do liberalismo político. No Brasil, estas tendências se traduziram na criação das autarquias reguladoras da produção e do comércio e na promulgação de programas e normas que legitimavam a posse, pelo governo, de meios decisivos para conduzir a vida econômica (Saravia 2004).

A partir dos anos 1930, o governo brasileiro deixou de priorizar a proteção do setor cafeeiro e alterou o foco da intervençáo estatal para a superação das falhas de mercado e a promoção da industrialização, tendo como uma de suas justificativas o ideal de nacionalizaçáo da economia. Para a ampliação e modernização da produção, uma grande capacidade financeira para investimentos era necessária, capacidade esta que muitas concessionárias privadas não dispunham (Fadul 1998: 3). Tendo em vista as dificuldades para os investidores privados desenvolverem a indústria primária no país - devido aos grandes montantes necessários para a sua construçáo e aos longos períodos de maturação- o governo ocupou parte desse setor com empresas estatais, no intuito de incentivar o crescimento do setor privado em outras áreas.

Getúlio Vargas, no seu primeiro governo (1930-1945), nacionalizou empresas de navegação, como a Company of Port of Pará e a The Amazon River Steam Navigation Company Ltd., fundindo-as no Serviço de Navegação da Amazônia e Administração do Porto do Pará. Foram nacionalizadas também várias empresas que prestavam os serviços de transporte pelos rios Paraná e Uruguai, consolidadas, em 1943, na empresa Serviço de Navegação da Bacia do Prata. Ainda foi desapropriado o patrimônio do armador Companhia Lage e Irmáos, criando assim a Companhia Nacional de Navegação Costeira. Não somente a União criou empresas de porte, como também alguns estados o fizeram. Por exemplo, uma das mais importantes empresas aéreas brasileiras, a Viação Aérea de São Paulo (VASP), foi criada em 1935 pelo Governo do Estado de São 
Paulo.

A Segunda Guerra Mundial foi uma das motivações mais notáveis para a transformação do Estado em grande empresário. Nesta empreitada, o governo não somente justificava sua atuação através da necessidade de suprimento de insumos básicos como também pela importância de proteger a soberania da nação, de assegurar a segurança nacional (Saravia 2004). Foram criadas siderúrgicas, mineradoras, fábricas de motores, bancos de fomento, etc.

O número de empresas estatais seguiu se expandindo na segunda Era Vargas (1951 a 1954) e durante o governo Kubitschek (1956 a 1961), com grande concentração em infraestrutura -transportes, energia e telecomunicaçóes- e na produção de matérias-primas básicas - aço e petróleo (Pinheiro \& Oliveira Filho 1991). Assumiu-se uma intenção de intervenção racional e voluntária do Estado, para indução e orientação do crescimento econômico. Nesta época, a política econômica desenvolvimentista se somava aos argumentos interessados em assegurar a segurança nacional, reforçando o caráter interventor do Estado. Em 1952 foi criado o Banco Nacional de Desenvolvimento Econômico, organização com grande participaçáo no histórico do desenvolvimento econômico do país. Também nesta época foi criada a Petrobras, no intuito de se assegurar uma fonte interna de fornecimento de petróleo.

Algumas empresas criadas no governo Kubitschek, incumbidas da implantação do Plano de Metas, foram: Centrais Elétricas de Furnas (1957); Companhia de Eletricidade do Amapá (1950); Companhia Hidrelétrica do Vale do Paraíba (1960); Usinas Siderúrgicas de Minas Gerais (1956); Companhia Siderúrgica Vatu (1960); Rede Ferroviária Federal S.A. (1957); Serviço de Transporte da Baia da Guanabara (1959). Para a construção de Brasília, foi criada, 1956, a Companhia Urbanizadora da Nova Capital do Brasil.

O Estado não somente cumpriu o papel de investidor em diversos setores estratégicos, como também atuou indiretamente controlando os impostos, a taxa de câmbio, as importaçóes e exportaçóes. Além disso, concedia incentivos e financiava os projetos industriais da iniciativa privada. Para tanto, elaborava planos, programas e projetos e formava quadros para gerenciá-los (os chamados tecnocratas). Esse processo caracterizou-se por uma enorme concentraçáo de poderes e recursos nas mãos do governo federal, que relegava aos estados e municípios uma ação meramente supletiva. 
Durante os anos sessenta e setenta, o número de empresas estatais atingiu seus maiores quantitativos, crescimento este ocorrido principalmente no regime militar. Durante a ditadura brasileira (1964 a 1985) foram criadas 302 empresas estatais, enquanto que na Era Vargas, no governo Kubitschek e no governo Goulart foram criadas, respectivamente, 15, 23 e 33 empresas. A época caracterizada pelo desenvolvimentismo apresenta a maior expansão do setor empresarial público brasileiro. Segundo Saravia (2004), uma das grandes causas desse crescimento foi o comportamento das próprias empresas. Estas organizaçóes, uma vez instaladas, passavam também a prever suas necessidades futuras e se mobilizavam para atendê-las. Tendo em vista novas demandas, oportunidades ou gargalos de produção, essas estatais procuravam se aparelhar, lançando máo de sua autonomia na busca de sua sobrevivência.

Existem também outros motivos para a expansão das estatais neste período que diferem das décadas anteriores, principalmente quanto aos objetivos. Muitas dessas empresas não foram criadas pelo Estado, mas sim adquiridas do setor privado por estarem em dificuldades financeiras. Esta medida, além de retirar as empresas da insolvência financeira, buscava manter o nível do emprego ou mesmo atender a interesses políticos. Outra grande parcela do crescimento surgiu com a criação de subsidiárias em setores já ocupados pelo setor privado, mas que não alcançavam a eficiência desejada.

As EE criadas durante as décadas de 40 e 50 eram parte de um plano integrado e centralizado de intervenção estatal, bem articulado com o investimento privado, que permitiu ao país beneficiar-se de significativas economias de coordenação e promover com sucesso a substituição das importaçóes nos anos 50. Diferentemente dessas primeiras EE, as subsidiárias criadas de forma descentralizada no final da década de 60 e nos anos 70 operavam em alguns dos setores mais lucrativos da economia onde passaram a competir com as empresas privadas (Pinheiro \& Oliveira Filho 1991:10).

Esta vertiginosa expansão da atividade empresarial do Estado não era, necessariamente, vista como uma política monopolizadora. Como exposto no trecho a seguir, a ação empresarial, antes de 1960, visava preencher "espaços vazios" na indústria nacional.

O crescimento contínuo da participação do Estado nas atividades econômicas no Brasil nas últimas três décadas foi quase inevitável. O setor privado brasileiro ainda é relativamente pequeno e não está em condiçóes de exercer um papel importante nas enormes necessidades de infraestrutura do país ou nas indústrias de tecnologia 
mais sofisticada, que também são as mais dinâmicas: petroquímica, siderurgia, equipamento de transporte etc. Logo, o crescimento do Estado não deve ser considerado como uma ameaça às empresas privadas brasileiras (Baer, Kerstenetzky \& Villela 1973, 281).

No plano ideológico, é importante ressaltar que a intervenção estatal na economia também se fez marcante por vários anos na maioria dos países desenvolvidos, não se restringindo apenas aos países em desenvolvimento. A proliferação de empresas públicas esteve diversas vezes relacionada à implantação de programas de bem-estar social, à melhoria da distribuição de renda e à aceleração do crescimento dos níveis de emprego. As raízes do estado Keynesiano e do Estado de bem-estar social foram plantadas em vários países em crescimento, e as teorias relativas aos conceitos de bens públicos e externalidades vieram oferecer a base teórica que justificava a maior participação estatal na economia.

Durante os anos setenta, os presidentes militares seguiam com o processo de consolidação do setor empresarial estatal. Foram construídas grandes obras de infraestrutura, como as usinas de Itaipu (hidrelétrica) e de Angra dos Reis (nuclear), os metrôs do Rio de Janeiro e de São Paulo e a Ferrovia do Aço. No governo de Emílio Médici foram criadas diversas holdings de destaque: Telecomunicações Brasileiras S.A.; Siderúrgica Brasileira S.A. e a Empresa Brasileira de Infraestrutura Aeroportuária. Já no período de Ernesto Geisel, foi criada a Portos Brasileiros S.A. e a Indústria de Material Bélico do Brasil. Além dessas, várias subsidiárias da Petrobras e da Vale do Rio Doce surgiram, tornando estas empresas grandes holdings ainda que seguissem com suas atividades de produção direta.

Um dos aspectos centrais das décadas de 1960 e 1970, período de maior expansão do setor empresarial público, foi o descontrole sobre o processo.

\section{Quadro 1: Época de criaçáo das empresas estatais}

\begin{tabular}{cc} 
Períodos & Número De Empresas \\
\hline Até 1930 & 17 \\
De 1930 a 1950 & 18 \\
De 1951 a 1960 & 37 \\
De 1961 a 1970 & 147 \\
De 1971 a 1976 & 131 \\
Não identificado & 221 \\
Total & 571
\end{tabular}

Fonte: Quem é Quem na Economia Brasileira (1976). 
O artigo “Quem é Quem na Economia Brasileira” (1976) apresenta um levantamento de uma amostra do número de empresas estatais criadas, agrupando-as por década. É perceptível uma aceleração na criação das estatais a partir da década de 1960 e uma aceleração ainda maior na década seguinte; porém, esse número é possivelmente ainda maior, já que o artigo supôe que as empresas que não tiveram o seu ano de criação identificado foram fundadas a partir de 1960.

No cenário internacional, ao final de 1970, o modelo em questão começava a dar sinais de esgotamento. A crise do petróleo e, pouco mais tarde, a crise dos juros da dívida externa soou o alarme da redução da capacidade do Estado em financiar o desenvolvimento. Em diversos países, a confiança no Keynesianismo foi abalada, refletindo no enfraquecimento das políticas econômicas de manutenção do pleno emprego e das práticas fiscalistas. Por outro lado, foram fortalecidas as orientaçôes monetaristas e de combate à inflação. O Brasil encaixava-se nesse panorama, pois suas políticas viam-se enfraquecidas devido à deterioração das finanças públicas. As subvenções destinadas às empresas, estatais e privadas, converteramse num grande peso para o orçamento, afetando o controle do gasto público e estimulando o debate acerca das estatais. Com isso, as pressóes desestatizantes ganhavam ainda mais força.

\section{MOVIMENTOS PRELIMINARES NO SENTIDO DA DESESTATIZAÇÃO - 1980 A 1990}

As duas crises do petróleo, em 1974 e 1979, a alta das taxas de juros no mercado financeiro internacional e a valorização do dólar ocasionaram mudanças globais no sistema de preços relativos, afetando sobremaneira a economia brasileira, que era atrelada ao sistema financeiro internacional. O governo, considerando inicialmente que essa conjuntura era passageira, manteve a política de captação de financiamentos externos e internos, agravando a situação financeira do Estado e de suas empresas com a alta dos juros.

O governo adotou políticas de achatamento dos preços públicos, estratégias conflitantes com a lógica empresarial, penalizando o desempenho das empresas públicas. Não somente a autonomia das estatais para definirem seus preços foi restringida, como suas receitas foram utilizadas para fins de ajuste financeiro das contas nacionais. Paralelamente, a intervenção indireta do Estado na economia, através do controle generalizado dos preços e da interferência nas decisóes privadas de investimento, constituiu outro fator de agravamento da crise. 
As formas de produção passavam por significativos avanços tecnológicos que transformaram o ambiente competitivo organizacional, demandando mais flexibilidade das empresas, característica que as estatais, sujeitas a um grande número de normas e restriçóes burocráticas, tinham dificuldade de oferecer. Por outro lado, a evolução técnica reconfigurou as estruturas de alguns mercados, abrindo espaço para a participaçáo do setor privado onde antes existiam monopólios públicos.

$\mathrm{Na}$ década de oitenta, marcada por uma onda neoliberal, as falhas da intervenção estatal foram sublinhadas e a confiança nas forças livres do mercado foi retomada. A grave crise econômica que o Brasil e outros países na América Latina passavam estimulou a adoção de políticas de privatizaçáa, como parte do processo de reformulaçáo e recuperação da capacidade de investimento e gerenciamento do Estado. A privatização era vista como meio para a redução do déficit público e de controle da inflação, gerando dois benefícios principais. Primeiro, a receita obtida com a venda das estatais poderia cobrir parte do estoque da dívida. Segundo, a transferência de empresas ao setor privado reduziria o montante das dívidas públicas e desobrigaria o Estado de realizar uma série de investimentos, relativos às empresas alienadas. Com isso, a poupança do governo seria beneficiada.

Os processos de privatização eram recomendados pelos organismos internacionais, como o Banco Mundial e o Fundo Monetário Internacional (FMI), aparecendo, inclusive, como condiçáo para concessão de empréstimos por parte dessas instituiçóes. Do ponto de vista das relaçóes internacionais, as medidas supracitadas adotadas pelo governo brasileiro reforçaram a credibilidade da política interna e externa, ao demonstrar que o governo realmente pretendia mudar o rumo da política intervencionista e reduzir o tamanho do Estado.

Durante o governo Figueiredo (1979-1985) foram realizadas 42 desestatizaçóes. Destas, 20 foram privatizaçóes federais, 3 estaduais, 3 empresas fundidas e 14 incorporadas. Nesta última fase da ditadura militar, o objetivo das privatizaçóes não era combater a ineficiência do setor público produtivo, mas sim desacelerar a sua descontrolada expansão.

No Brasil, os primeiros passos rumo à privatização começaram com o Decreto N. ${ }^{\circ} 83.740 / 1979$, que criou o Programa Nacional de Desburocratização. Em 1981, foi criada a Secretaria Especial de Controle das Empresas Estatais (Sest), órgáo que viria a ter destaque no controle dos gastos e investimentos das empresas públicas. 
Em seu primeiro censo, a Sest identificou 505 instituições sob controle da União. O que evidenciava o crescimento desordenado do número de estatais ocorrido na década de 1970 era a observação de que, das 268 empresas estatais, apenas 40 haviam sido criadas por lei. Ainda, das 228 restantes, 76 foram absorvidas do setor privado, por estarem em processo de falência (Pinheiro \& Oliveira Filho 1991). Tendo em vista essa informação, em julho do mesmo ano, foi criada a Comissão Especial de Desestatização, que restringiu a instituição de novas empresas públicas e estabeleceu diretrizes para a transferência destas para o setor privado.

A Comissão Especial de Desestatização chegou a identificar 140 empresas para privatizar no curto prazo. O primeiro grupo a ser alienado era composto por 50 empresas, porém, o saldo do processo atingiu um total de apenas 20 empresas. De resto, uma empresa foi alugadas e oito incorporadas a outras instituiçóes públicas. Por outro lado, enquanto essas desestatizaçóes aconteciam, mais seis empresas privadas passaram para o controle do Banco Nacional de Desenvolvimento Econômico e Social (BNDES). Como resultado, as privatizaçôes foram consideradas um fracasso, já que, no geral, as poucas empresas vendidas eram, na verdade, reprivatizadas. Ainda, nenhuma das grandes estatais foi alienada, seja pelas restriçốes aos potenciais compradores, seja pela necessidade de liberalização da economia. Os principais ganhos obtidos não foram, portanto, as vendas das empresas, mas sim o acúmulo de experiência e conhecimento acerca da identificação de quais empresas alienar, que processos utilizar, como superar as oposiçóes, além dar publicidade ao tema (Pinheiro \& Oliveira Filho 1991). 


\section{Quadro 2: Privatizaçóes ocorridas entre 1981 e 1984}

\begin{tabular}{|c|c|c|c|}
\hline Empresa & Setor & $\begin{array}{l}\text { Data Da } \\
\text { Venda }\end{array}$ & $\begin{array}{c}\text { Valor Venda } \\
\text { (Us\$ Milhóes) }\end{array}$ \\
\hline Cia. Química do Recôncavo & Química & Nov. 1981 & 5,1 \\
\hline Cia. América Fabril & Têxtil & Nov. 1981 & 28,8 \\
\hline Riocell Adminst. S.A. (holding) & Celulose & Mar. 1982 & 77,6 \\
\hline Riocell (Trade GMBH) & Celulose & Mar. 1982 & - \\
\hline Rio Grande Cia. de Celulose do Sul & Celulose & Mar. 1982 & - \\
\hline Florestal Rio Cell & Celulose & Mar. 1982 & - \\
\hline Fábrica de Tecidos Dona Isabel & Têxtil & Jul. 1982 & 16,9 \\
\hline $\begin{array}{l}\text { Método Org. Plan. e Adm de Sistemas } \\
\text { Empresariais Ltda. }\end{array}$ & Consultoria & Jun. 1982 & 0,1 \\
\hline Ind. Brasileira de Papel & Papel & Ago. 1982 & 3,2 \\
\hline Cia. Pernambucana de Borracha Sintética & Borracha & Dez. 1982 & 24,8 \\
\hline $\begin{array}{c}\text { Óleos de Palma S.A - Agroindústria } \\
\text { Opalma }\end{array}$ & Óleos Vegetais & Mar. 1983 & 3,1 \\
\hline Federal de Seguros S.A. & Seguros & Abr. 1983 & 7,1 \\
\hline Nitriflex S.A - Indústria e Comércio & Química & Abr. 1983 & 5,4 \\
\hline Cia. Brasileira de Cimento Portland Perus & Cimento & Abr. 1983 & 15,9 \\
\hline Força e Luz Crisciúma S.A. & Energia & Mai. 1982 & 2,8 \\
\hline Livraria José Olympio Editora & - & Mai. 1982 & - \\
\hline Encine Audiovisual S.A. & Editora & Abr. 1984 & 0,3 \\
\hline Sidacta S.A. & Editora & Abr. 1984 & - \\
\hline Fiação e Tecelagem Lutfala & Têxtil & 1984 & 0,002 \\
\hline Subtotal $1981-1984$ & & & 191,1 \\
\hline
\end{tabular}

Durante a redemocratização do país, ocorrida no Governo Sarney (1985-1990), foi criado o Conselho Interministerial de Privatização, em substituição da Comissão Especial de Desestatização, com vistas a aumentar a transparência e o apelo político do processo da privatização, que agora compreendia a abertura do capital social, a alienação de participaçóes societárias e a desativação de empresas sob o controle do governo federal. 
O primeiro governo democrático posterior ao período militar de 19641984 caracterizou-se pelos esforços em dominar a hiperinflaçáo sem lançar mão de políticas econômicas ortodoxas. Mesmo ao final do governo de Sarney, a austeridade fiscal, a liberalizaçáo comercial, as privatizaçóes e a desregulação seguiam sendo assuntos pouco debatidos entre os burocratas e acadêmicos. A aliança democrática, contrária ao autoritarismo característico do período militar, visava, essencialmente, à correção das estratégias impositivas de crescimento, procurando assegurar um viés mais social e democrático às reformas (Almeida 1996).

Apesar da série de decretos e projetos de lei que ampliaram o programa de desestatização, os processos de privatização não tiveram grande força, pois não havia um acordo político entre o Executivo e o Legislativo. Segundo Velasco (1997), as alienações neste governo tiveram pouca relação com o Conselho de Desestatização, sendo impulsionadas principalmente pela ação do BNDES em busca de uma reciclagem alocativa de seus recursos, no intuito de fortalecer as intervençôes em outros setores econômicos. Durante o período realizaram-se 17 processos de desestatização, gerando uma arrecadação de US\$ 549.000.000 e uma transferência de dívidas ao setor privado de US\$ 620.000.000. Tiveram destaque as alienaçóes da Eletrosiderúrgica Brasileira (maior produtora de ferros-liga à época), da Aracruz Celulose (até hoje uma das maiores do setor), da Caraíba Metais (única metalúrgica de cobre do país).

No entanto, 11 destas privatizaçóes foram de empresas controladas pelo BNDESPAR, subsidiária integral do BNDES, e duas conduzidas por esta organização, na qualidade de agente de privatização. O BNDES esclarece alguns determinantes das suas alienaçóes no documento "Privatização: a experiência do BNDESPAR no período 1987-1989”. O grande número de empresas controladas por esta subsidiária chegou a concentrar $50 \%$ do volume de desembolsos no período 1982-1985, desembolsos estes que custeavam gastos decorrentes das controladas. Com isso, os investimentos em participações minoritárias, objetivo social da instituição, se viam prejudicados. O motivo acima e outros enumerados no documento permitem perceber que as explicaçóes para as alienaçóes não passam por questóes ideológicas ou por pressóes externas, mas sim no interesse da instituição em tomar açôes estratégicas para o seu interesse (Velasco 1997).

Em 1989, de acordo com o Sest, existiam 230 empresas estatais federais (179 do setor produtivo) e 28 concessionárias estaduais de energia. No Governo Sarney (1985-1990) foram realizadas 42 desestatizaçóes, sendo 18 privatizaçóes, 2 incorporaçóes, 4 empresas extintas e 18 transferidas aos governos estaduais. 
Do ponto de vista legal, um passo relevante que contribuiu para os futuros processos de desestatização foi o Decreto N. ${ }^{\circ}$ 95.886/1988, que incluiu pela primeira vez os conceitos de desregulaçáo e a possibilidade de concessáo de serviços públicos para empresas privadas. A Constituição de 1988 já previa a possibilidade da prestação de serviços públicos e de atividades monopolizadas pelo Estado por agentes privados, possibilidade esta posteriormente regulada no governo de FHC.

\section{INTENSIFICAÇÃO E ÁPICE DAS PRIVATIZAÇÓES - 1990 A 2002}

Em 1990, ascendia ao poder o primeiro presidente eleito por voto direto após o término da ditadura militar, Fernando Collor de Mello. Já no primeiro ano de mandato foi instituído o Programa Nacional de Desestatização (PND), que estabeleceu como metas de médio e longo prazo: a redução do endividamento público, a democratização do capital, a modernização e a ampliação da competitividade interna e o aumento da eficiência na produção de bens e serviços. Os esforços iniciais se concentraram na venda de 68 empresas estatais dos setores siderúrgico, petroquímico e de fertilizantes. Apesar das intenções do governo, prematuramente extinto ${ }^{1}$, apenas 18 destas empresas selecionadas foram vendidas, arrecadando receitas no valor de US\$ 4 bilhóes. Destas receitas, grande parte foi paga através de moedas de privatizaçáo ${ }^{2}$, no caso, títulos públicos de longo prazo com valor de mercado muito inferior ao valor de face. A permissão de uso desse meio de pagamento acabou por prejudicar severamente o saldo destas privatizaçóes.

O substituto de Fernando Collor, Itamar Franco (1992-1994), preocupou-se em suspender os leilóes de privatizaçáo já marcados. Como o equívoco da utilização de moedas de privatizaçáo já havia sido percebido,

1 Collor sofreu impugnação de mandato (impeachment), forçando-o a renunciar em dezembro de 1992.

2 O processo de privatização brasileiro admitiu outros meios de pagamento além da moeda corrente: as chamadas "moedas de privatização". São dívidas contraídas no passado pelo Governo Federal, aceitas como forma de pagamento das açóes das empresas estatais que estavam sendo privatizadas. A intenção era reduzir o endividamento e acabar com os compromissos financeiros provenientes dessas dívidas (Lustosa da Costa \& Peci 1999). Cabia ao Presidente da República decidir sobre o percentual mínimo de moeda corrente a ser utilizada na privatizaçáo de cada empresa. O percentual restante podia ser complementado com as moedas de privatização. As moedas de privatização utilizadas no PND eram as seguintes: Debêntures da Siderbrás; Certificados de Privatização; Obrigaçóes do Fundo Nacional de Desenvolvimento; Créditos Vencidos Renegociados (securitizados); Títulos da Dívida Agrária; Títulos da Dívida Externa; Letras Hipotecárias da Caixa Econômica Federal; Notas do Tesouro Nacional, série M-NTN. 
foi enfatizado o uso da moeda corrente durante as novas privatizaçôes. Também se percebeu que as regras que discriminavam os investidores estrangeiros limitavam as concorrências nas licitaçóes, e, por isso, foi aberta ao capital estrangeiro a possibilidade de participaçáo nos certames. Com isso, maiores preços de venda poderiam ser obtidos. Durante estes dois anos, o resultado foi de US $\$ 4,5$ bilhões, provenientes da venda de 15 empresas.

As privatizaçóes planejadas para o período 1990-1994 não ocorreram de acordo com o desejado, e, segundo Rosa \& Senra (1995), vários fatores inibiram o processo de privatização. Os principais obstáculos foram: o impacto do processo de impeachment do ex-presidente Collor; a corrupção política apurada pela Comissão Parlamentar de Inquérito do Orçamento da União, destacando as verbas dadas aos parlamentares corruptos por empreiteiras para garantir as privatizaçôes que lhes interessavam; o fracasso da revisão da constituição em 1994; o movimento da sociedade pela ética na política e no Estado, simbolizado por Herbert Souza "Betinho"; a dificuldade política de articular os diferentes agentes e governos estaduais em torno de uma dada estratégia de privatização.

O resultado acumulado das privatizaçóes deste período foi de US\$ 11,9 bilhôes, sendo 8,6 bilhóes de receita das vendas e 3,3 bilhóes de transferência de dívidas. As moedas de privatizaçáo representaram $81 \%$ da receita obtida com as vendas das empresas no âmbito do PND (BNDES 2002).

As privatizaçóes ocorridas nos governos Sarney, Collor e Franco tiveram como foco as empresas industriais públicas, tendo como essencial motivação obter reajustes fiscais, ao cortar investimentos e custos desnecessários ou descontrolados. Os debates giravam em torno destes temas, mas não haviam ingressado na definição de um novo papel do Estado na economia. Este reposicionamento seria a tônica do governo de FHC, para isso, o processo de privatizaçóes foi intensificado e tornou-se a dimensão central da reforma. Visando à mudança da ordem econômica, empreendeu-se uma reorientação do papel do Estado, no intuito de reduzir sua intervenção e estabelecer a prevalência do mercado como condutor na economia. A privatização, além de ser considerada um meio de redução da dívida pública, passou a ser também parte do processo que visava aumentar a eficiência do sistema econômico (Lustosa da Costa \& Peci 1999).

O enfoque nas privatizaçôes foi de tal sorte que, das três dimensóes da reforma empreendida -patrimonial, gerencial e tributária-, as açóes relativas à redução do aparelho estatal, via alienaçóes, tomaram grande parte da agenda de governo (Lustosa da Costa \& Peci 1999). A reforma 
tributária não ocorreu nos mandatos de FHC, sendo realizada no governo de seu sucessor. Por sua vez, a reforma gerencial aconteceu, mas foi insatisfatória no que diz respeito à sua execução e aos seus resultados.

Além das empresas federais, as privatizaçóes passaram a abranger também as empresas estaduais, seja por aderência destes entes ao programa, seja por imposição do governo federal. Nas rodadas de renegociação de dívidas, os estados eram estimulados a desenvolver programas de venda dos bancos e empresas de energia elétrica estaduais. Outros, por sua vez, aderiram ao programa por iniciativa própria, transferindo também empresas e serviços de outros setores.

Em 1997 foi privatizada uma das mais importantes empresas estatais do setor produtivo, a Companhia Vale do Rio Doce, na época a maior produtora e exportadora de minério de ferro no mundo e a maior produtora de ouro na América Latina. Essa privatização era, até então, a mais expressiva. No leiláo do controle da empresa foram alienadas 99 milhóes de ações ordinárias nominativas, correspondendo a uma arrecadação de US\$3, 1 bilhóes. Também em 1997, mesmo que os montantes esperados não fossem alcançados, as entradas de recursos ocorridas no Governo FHC, até então, já eram quase três vezes maiores que as receitas obtidas no Governo Collor.

Concluída a alienação do SPE, uma nova fase se inaugurava com a privatização da infraestrutura e das concessóes de serviços públicos. Diversas mudanças constitucionais e legais foram executadas visando reforçar (ou reformular) a capacidade do Estado nas suas funçóes de planejamento, regulação, controle e fiscalização. A Lei de Concessôes N. ${ }^{\circ}$ $8.987 / 1995$, nascida do projeto do então senador FHC, definiu as figuras de concessão de serviço público, aplicando-se principalmente aos setores de energia elétrica e de transportes. Estas concessóes diferem das vendas de empresas estatais, porque os agentes privados assumem não apenas o direito de prestar determinado serviço público, mas também a obrigação de fazê-lo por um período pré-definido. Também são outorgados os direitos de uso de ativos públicos, que devem ser zelados pelos agentes privados e revertidos ao Poder Concedente ao final do contrato. Em contrapartida, as concessionárias devem apresentar planos de investimentos, financiados pela cobrança de taxas dos usuários dos serviços, desobrigando assim o Estado de investir seus recursos nestes setores e permitindo a alocação de recursos em setores considerados prioritários. Juntamente com a figura de concessão, a Lei Geral das Concessốes prevê a criação das autarquias reguladoras, com o objetivo de criar condições favoráveis para o processo de concessão dos serviços públicos e regular a prestaçáo desses serviços. 
O desenvolvimento do regime regulatório brasileiro pode ser utilizado como base para a crítica da reforma gerencial empreendida. Por exemplo, a análise do histórico do setor rodoviário e de sua agência reguladora, a Agência Nacional de Transportes Terrestres (ANTT), demonstra graves deficiências. As primeiras concessóes de rodovias datam de 1995 e, até 2001, inexistia, no âmbito federal, uma organizaçáo especificamente criada para regular as rodovias, doravante importância logística do setor para o país. Institucionalmente, o Departamento Nacional de Estradas e Rodagens, que detinha atribuiçóes tipicamente executivas, foi o responsável pelos certames, pela regulação dos serviços e pela fiscalização dos convênios de delegação aos estados. Esta consolidação num mesmo órgão de funçôes de regulação, planejamento, execução dos contratos de concessão e administração direta das rodovias criou uma série de conflitos que prejudicaram o alcance dos objetivos das concessóes rodoviárias (Neves 2006).

A exemplo da União, muitos estados transferiram suas rodovias sem o estabelecimento de agências reguladoras que fiscalizassem os serviços prestados, apesar do auxílio do BNDES, gestor do FND e executor dos processos de privatização através do Programa de Estímulo às Privatizaçóes Estaduais. Ainda, na Lei de Concessóes não constam os princípios, diretrizes e regras gerais que deveriam ser obedecidas no ordenamento das agências, dificultando a uniformidade em relação a questôes essenciais como: os objetivos da regulação, funçóes e principais atribuiçóes das agências; a estrutura organizacional e de custeio destas; a formatação jurídica do órgão e o grau de independência em relação ao poder público (Moraes 1997).

$\mathrm{Na}$ realidade, a única agência reguladora que começou a funcionar antes das privatizaçôes foi a Agência Nacional de Telecomunicaçóes (ANATEL). Logo, não por acaso, as privatizaçóes nessa área puderam ser consideradas bem-sucedidas e os resultados da atividade dessa agência mais satisfatórios (Lustosa da Costa \& Peci 1999). A venda das empresas do setor de telecomunicações tornou-se possível com a aprovação da Lei das Telecomunicaçôes (Lei N. ${ }^{\circ}$ 9.472/1997), que, além de fornecer as orientaçôes sobre a transferência deste serviço público e dos ativos envolvidos, criou, na qualidade de órgão regulador, a ANATEL. Em 1998 o governo federal privatizou 12 holdings -criadas a partir da cisão do Sistema Telebrás- transferindo para a iniciativa privada três empresas de telefonia fixa e oito de telefonia celular (Banda A). A arrecadação somou US\$18,3 bilhóes e o ágio médio foi de $53,74 \%$ sobre o preço mínimo. Além da Embratel, operadora de serviços de longa distância, no ano seguinte, o governo licitou concessóes para exploração de quatro áreas de telefonia fixa das empresas-espelho, possibilitando a concorrência com as companhias de 
telecomunicações privatizadas, no intuito de melhorar a eficiência do setor, assim como gerar maiores receitas de vendas. $\mathrm{O}$ processo de privatizaçáo deste setor foi de grande relevância, visto que foi responsável por uma entrada de recursos no valor de US\$32.758.000.000, correspondendo a $31 \%$ do total de receitas das privatizações entre 1990 e 2002.

O setor elétrico federal teve como início de sua desestatização a venda da Espírito Santo Centrais Elétricas S.A., seguida da privatização da Light Serviços de Eletricidade S.A. e Gerasul. No âmbito estadual, foram privatizadas 20 empresas do setor elétrico, sendo 17 distribuidoras e três geradoras. O resultado total das privatizaçôes deste setor, até 2002 , foi de US \$29, 8 bilhôes, sendo US\$22,2 bilhôes de receitas de vendas e US\$ 7,5 bilhões de transferências de dívidas.

No governo FHC, o resultado acumulado das privatizaçóes foi de US\$ 93,4 bilhóes, sendo 14,8 bilhôes de receita das vendas e 78,6 bilhóes de transferência de dívidas (88,8\% do total de receitas entre 1990 e 2002). Houve uma redução da utilização de "moedas de privatização" e aumento do ingresso de moeda corrente nacional, que passou a representar $95 \%$ do total arrecadado nos leilóes de privatização (de 1990 a 1994 esta parcela foi de 19\%). Outra diferença do PND no governo FHC foi quanto à participaçáo do capital estrangeiro, que atingiu 53\% do total arrecadado com todas as desestatizaçóes realizadas no país, enquanto que, no período de 1990 a 1994 , somente 5\% das receitas de vendas das privatizaçóes foram de investidores estrangeiros. De 1995 a 2002 as empresas nacionais responderam por $26 \%$ da receita, cabendo $8 \%$ às pessoas físicas, $7 \%$ às entidades do setor financeiro nacional e $6 \%$ às entidades de previdência privada.

Enquanto o setor de infraestrutura/serviços arrecadou o total US\$ 63,2 bilhões, as privatizações de empresas industriais corresponderam a US\$ 10,9 bilhôes. O gráfico abaixo apresenta a evolução anual das receitas de privatizaçóes, passando pelos governos Collor, Itamar Franco e FHC. 
Figura 1: Receitas de privatizaçóes segundo ano, em US\$ bilhóes, de 1991 a 2002

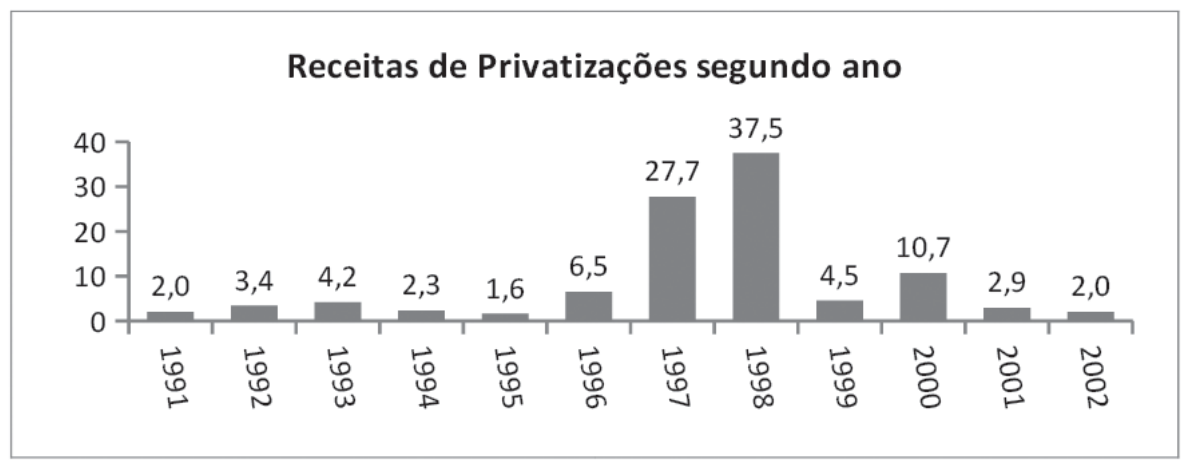

Fonte: BNDES, Privatizaçôes no Brasil 1990/2005 (2006).

As decisóes do governo acerca das alienaçóes, por vezes, passaram por cima de diversas críticas, vindas essencialmente do movimento sindical e de políticos de esquerda, ambos contrários às vendas. Pouco se considerou as opinióes de grupos que náo eram contra as privatizaçóes, mas que criticavam a forma como foram leiloadas as estatais. No saldo final, FHC vendeu boa parcela do patrimônio industrial e de serviços públicos construídos em décadas (Belieiro Junior 2007). O BNDES, que desde o início foi o gestor do PND, agiu ativamente como financiador dos compradores, independente destes serem bancos privados, empresas nacionais ou estrangeiras. Os empréstimos às empresas privadas, sobretudo no setor de infraestrutura, foram bastante relevantes, fato que, de certa forma, contraria uma das justificativas para as privatizaçóes: a incapacidade do Estado de investir na melhoria e recuperação de seus serviços devido à crise fiscal (Belieiro Junior 2007, Lustosa da Costa \& Peci 1999).

Após mais de uma década do auge do processo de privatização alguns indícios apontam que seus resultados náo ocorreram no modo ou intensidade que se previa. $\mathrm{O}$ ajuste fiscal, um dos principais (senão o principal) objetivo da reforma patrimonial, não foi satisfatório e a renda obtida não proporcionou ganhos fiscais duradouros. Em primeiro lugar, a receita proveniente das privatizaçóes pouco auxiliou na reduçáo do endividamento, principalmente devido à elevada taxa real de juros vigente desde o início do Plano Real. Entre 1995 e 2003, a dívida líquida do setor público cresceu de $27,98 \%$ para $52,36 \%$ do PIB. Em valores brutos, a dívida pública passou de US\$ 70 bilhóes para US\$ 400 bilhóes. O efeito redutor das privatizaçóes sobre o endividamento não passou de 3,65\% do PIB até 2003, não compensando nem mesmo o efeito contrário do ajustamento patrimonial (esqueletos), que era de 5,35\% do PIB. Em 
segundo lugar, os valores obtidos com a alienaçáo de algumas empresas revelam ter sido baixos, como é o caso da Companhia Vale do Rio Doce e das privatizaçôes pagas com moedas de privatização (Gobetti 2010).

É interessante ressaltar que o tamanho do governo ${ }^{3}$, medido pela soma das despesas de custeio do governo com as despesas de custeio das estatais produtivas federais, em termos do PIB, manteve-se relativamente constante.

\section{Figura 2: Despesas de Custeio do Governo Federal e das Empresas Estatais (em \% do PIB)}

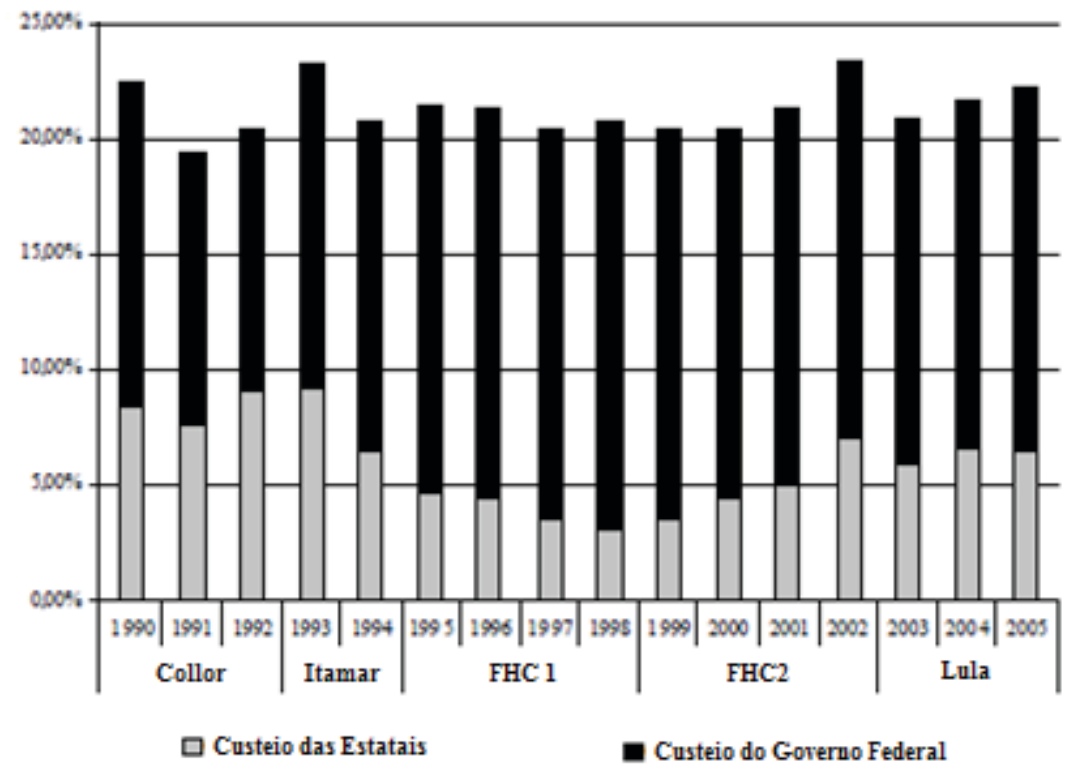

Fonte: Adaptado de Arvate \& Maciel (2010).

Para a construção das séries de dados do "tamanho" do governo foram consideradas as despesas correntes do governo federal, obtidas a partir dos dados de consumo do governo (despesas com custeio: máo de obra, materiais de consumo etc.) subtraindo-se os pagamentos de juros e encargos da dívida pública e as transferências a Estados, Distrito Federal e Municípios. O valor resultante foi, então, calculado em proporção do PIB.

3 O percentual das despesas de custeio do governo em termos do PIB é a medida internacional de comparação do "tamanho" dos governos para países da OCDE. Porém, a história dos países latino-americanos, que passaram por períodos desenvolvimentistas, não permite que se discuta o tamanho de governo sem se considerar as empresas estatais (Arvate \& Maciel 2010). 
No gráfico, ao se observar o primeiro mandato de FHC -período com maior saldo de privatizações-, é perceptível uma queda das despesas de custeio das estatais produtivas, que, no entanto, é compensada por um crescimento das despesas de custeio da administraçáo federal. Com isso, o "tamanho" do Estado mantêm-se relativamente constante. Esta informação reforça argumentos de que o governo brasileiro se concentrou no processo de desestatização, principalmente através da privatização, deixando à margem a reforma patrimonial. Os dados demonstram que o pretendido incremento da eficiência da Administração Pública, reduzindo assim os seus gastos, fez pouca diferença.

\section{RETOMADA DO MOVIMENTO DE ESTATIZAÇÃO - 2003 A 2010}

Durante sua campanha eleitoral de 2002, o então candidato à presidência, Luís Inácio "Lula" da Silva, publicou a Carta ao Povo Brasileiro, comprometendo-se em honrar os contratos relativos à dívida pública (doméstica e externa) e executar o programa de auxílio do FMI, negociado no governo de FHC (Lula 2002). Como era de se esperar, este documento não foi suficiente para diminuir a insegurança do mercado internacional. Em 2003, a posse do novo Presidente da República deixou os mercados, nacional e internacional, receosos quanto ao andamento das políticas econômicas brasileiras. Esta desconfiança existia já que, após uma década de privatizaçôes e de dois mandatos de um governo essencialmente neoliberal, ascendia ao poder um candidato de esquerda, com um público histórico de militância trabalhista e de crítica à submissão aos organismos econômicos internacionais.

A sucessão presidencial, no entanto, não apresentou rupturas com as políticas conservadoras do governo anterior, e o arrocho fiscal e os baixos níveis de investimento público não somente foram mantidos como também aprofundados. Os investimentos foram severamente reduzidos. Os montantes aplicados em 2003 e 2004, somados, não alcançavam os valores investidos por FHC em 2002. Portanto, o dilema fiscalismo versus desenvolvimentismo ${ }^{4}$ seguia como restrição à ação estatal, e a balança seguia apontando para o lado dos fiscalistas.

Este conservadorismo teve duas consequências principais. Por um lado, tranquilizou os investidores outrora receosos quanto à condução da

4 O dilema consiste na oposição das proposiçôes de fiscalistas e desenvolvimentistas. Enquanto os primeiros defendem o aperto fiscal, no (com o) objetivo de criar saldos suficientes para o pagamento da dívida e evitar seu crescimento adicional, seus antagonistas receitam maiores gastos públicos, objetivando estimular o crescimento econômico, de modo a combater a dívida pública sem desacelerar a economia. 
política econômica brasileira. Por outro, sinalizou pouco compromisso do governo, que tinha "escolhido" trocar de valores ao chegar ao poder, com seu histórico de militância (Cardim de Carvalho 2003, Paulani 2003, apud Morais \& Saad Filho 2011). No entanto, os movimentos de desestatização intensificados na década anterior perderam parte do seu ímpeto, apesar da continuidade da transferência de serviços públicos para a gestáo privada. Três fatos sustentam esta afirmação: o crescimento do número de empresas estatais federais, o reconhecimento público da importância destas organizaçôes na economia e o reforço da utilização destas empresas como instrumentos para a execução de políticas públicas.

O aumento do número de empresas estatais federais, por si só, não indica uma mudança de atitude do governo quanto a estas organizaçóes. É preciso investigar os motivos destes movimentos e, também, observar os movimentos de desestatização. Por exemplo, no segundo mandato FHC, o número de estatais federais cresceu aproximadamente 14\%. Porém, este crescimento entre 1999 e 2002 deveu-se, essencialmente, à transferência de empresas estatais municipais ou estaduais para o governo federal, realizadas como parte do processo de renegociação das dívidas de estados e municípios (Arvate \& Maciel 2010). As empresas transferidas e outras estatais não foram privatizadas devido à ausência de apoio popular e a presença de embates políticos e ideológicos em torno das privatizaçóes que estariam por vir (Pinheiro Giambiagi \& Moreira 2001).

Já durante o primeiro mandato de Lula, o número de estatais federais passou para 135 empresas em 2006 -eram de 106 empresas em 2002-, aumento este impulsionado principalmente pela expansão do Setor Produtivo Estatal.

Quanto ao aspecto fiscal das políticas econômicas, as empresas estatais agiram como contrapeso da retração da taxa de investimentos da União entre 2003 e 2005. Segundo o Dest, pelo critério do Programa de Dispêndios Global (PDG), as empresas públicas, que investiram US\$ 7,4 bilhôes deflacionados no país em 2002, passaram a investir 11,3 bilhóes em 2004 e alcançaram o total de 14,3 bilhóes em $2005^{5}$. O aumento nos níveis de investimento foi de grande auxílio para a situação fiscal e macroeconômica do país, amenizando os efeitos recessivos do aperto fiscal e monetário sobre a economia (Gobetti 2010). A contribuição das empresas estatais demonstrou que estas organizaçóes não são necessariamente nocivas ao bom funcionamento do Estado, nem da economia, como defendido pelos liberais.

5 Os relatórios anuais de execução orçamentária das estatais elaborados pelo DEST reúnem os dados de todas as empresas incluídas no PDG, excetuando-se entáo as empresas dependentes, custeadas com recursos do Orçamento geral da União. 
A análise das demonstrações financeiras das estatais assegura que, também no plano microeconômico, os resultados das empresas do setor produtivo foram satisfatórios. A receita líquida do SPE cresceu de US\$ 41 bilhôes em 1995 para US\$ 92 bilhóes em 2006, considerando os valores correntes ${ }^{6}$. No mesmo período, o lucro líquido passou de US\$1,7 bilhão para US\$12,8 bilhôes e a rentabilidade, medida em proporção do patrimônio líquido, cresceu de 1,8\% em 1999 -logo após as privatizaçóes do setor industrial- para 27,2\% em 2006. Apesar da redução no número de empresas, o SPE cresceu significativamente em receitas e em gastos no período em questão (Gobetti 2010).

Quanto ao tema das privatizaçóes, observa-se que, entre 1999 e 2006, a contribuição direta e indireta das estatais para o superávit primário totalizou US\$ 119 bilhóes em valores atualizados pelo deflator do PIB, totalizando um montante maior que toda a receita proveniente da alienação das estatais entre 1991 e 2002 . Porém, enquanto a receita proveniente de uma privatização é obtida apenas uma vez, a contribuição das estatais é contínua, podendo ser ajustada pelo governo de acordo com as necessidades econômicas do país. Portanto, é plausível considerar que o verdadeiro ganho fiscal decorrente da privatização foi proporcionado pelo fortalecimento e reorganização das estatais remanescentes, com destaque para a Petrobras (Gobetti 2010). A percepção de que a manutenção das estatais gerou mais benefícios fiscais no período do que a alienação de empresas públicas contrariou os prognósticos dos fiscalistas quanto às privatizaçóes e, consequentemente, fortaleceu os argumentos desenvolvimentistas. Este fato, possivelmente, contribuiu para a mudança de postura do governo quanto ao nível de intervenção estatal na economia e na valorização das empresas estatais, ocorrida a partir de 2006.

Durante os três anos iniciais do primeiro mandato de Lula, o ajuste fiscal não acelerou substancialmente o crescimento da economia, nem melhorou a renda e o nível de emprego. Neste momento, tanto os neoliberais como os desenvolvimentistas recomendaram mudanças nas políticas econômicas adotadas. Os desenvolvimentistas, que receitavam medidas monetárias e fiscais de estímulo ao crescimento para estimular o círculo virtuoso econômico, tinham suas idéias fortalecidas devido à fraqueza dos "novos" prognósticos neoliberais e pelo baixo crescimento econômico dos anos anteriores. Esta visão defendia o aumento do investimento público, elevando a demanda agregada e influenciando positivamente a produtividade e competitividade da economia brasileira, principalmente pela retomada dos investimentos nos setores de infraestrutura. Os defensores dessa vertente

6 A cotação do dólar passou de o, 97I reais em dezembro de I995 para 2,I38 em dezembro de 2006. 
receitavam, portanto, não somente o aumento nas transferências de renda e no salário mínimo, mas também no investimento por parte do governo federal e das estatais.

Neste contexto, três iniciativas tomadas na execução da política fiscal, ainda em 2006, marcaram o início do reposicionamento do governo federal quanto ao nível e grau de intervenção estatal na economia: a elevaçáo substancial no salário mínimo (em 2006 o salário mínimo subiu 16,7\%); o aumento no investimento público (incluindo o das empresas estatais); e a reestruturação de carreiras e salários dos servidores públicos (Barbosa 2010). De acordo com sua nova orientação mais desenvolvimentista, em 2006, o governo federal desenvolveu um programa emergencial para o setor rodoviário que, apesar de pequeno em valor (US\$ 199 milhóes), constituiu um marco importante da mudança nas prioridades estatais. Este reposicionamento foi determinante no início do segundo mandato, em 2007, quando as políticas federais seriam reorganizadas, centralizadas e ampliadas, com o desenvolvimento do Programa de Aceleraçáo do Crescimento (PAC) (Barbosa 2010).

A mudança do governo quanto à condução das políticas econômicas se consolidou, tendo como principal evento o início do PAC. Este programa plurianual previa um total de investimentos em infraestrutura de US\$ 303,8 bilhôes considerando valores do Orçamento Geral da União e os realizados por empresas estatais. No entanto, esta iniciativa não somente deu seguimento à inflexão no nível de investimento público como indicou a recuperação do papel do Estado no planejamento de longo prazo, em especial nos setores de infraestrutura, articulando as participações estatal e privada fundamentalmente através de concessóes ou parcerias. Em ambos os casos, o governo exerceu papéis centrais na coordenação dos projetos, na garantia da demanda e no financiamento de longo prazo. Além dos investimentos em infraestrutura, o plano tinha mais quatro blocos: estímulo ao crédito e financiamento, melhora do ambiente de investimento, desoneração e reforma do sistema tributário, medidas fiscais de longo prazo.

Grandes aumentos da taxa de investimento federal direcionavam-se aos transportes. Os montantes aplicados em ferrovias mais que triplicaram em valores reais de 2005 a 2009, enquanto os investimentos em transporte hidroviário mais que quadruplicaram no período. Em ambos os casos, o crescimento foi influenciado por grandes obras, como a Ferrovia NorteSul (US\$ 410,06 milhóes somente no ano de 2009) e a construção das eclusas de Tucuruí no rio Tocantins, no estado do Pará (cerca de US\$ 254,42 milhóes em 2009) (Orair \& Gobetti 2010). Vale ressaltar que esta multiplicação das taxas de investimento é proveniente, essencialmente, dos 
níveis muito baixos apresentados nos anos anteriores. As açóes relativas ao modal rodoviário, que representou $70 \%$ da expansão do setor de transportes no período, incorporaram tanto intervençóes estatais diretas como o fortalecimento da atividade reguladora do Estado, devido à ampliação das concessóes. A ANTT licitou $2.600 \mathrm{~km}$ de rodovias federais e foram incluídos no PND as concessões de aeroportos, novas rodovias, trechos de rodovias federais existentes e o Trem de Alta Velocidade.

Além do aumento dos investimentos públicos, o governo interferiu na economia em mais dois pontos cruciais: 1) no aumento das transferências de renda e na elevação do salário mínimo; 2) na adoção de medidas temporárias de estímulo fiscal e monetário. O objetivo da primeira medida era acelerar o desenvolvimento social. Sua execução ocorreu principalmente através da expansão da Bolsa Família -programa de garantia de renda mínima para famílias mais pobres- e da elevação do salário mínimo real, que cresceu aproximadamente $18 \%$ no período do segundo mandato de Lula. Já a segunda medida objetivava, inicialmente, acelerar o crescimento e elevar o potencial produtivo da economia. Somente em 2007, a desoneração tributária representou uma renúncia fiscal de US\$3,73 bilhóes. A partir da crise econômica mundial de 2008, esta linha de atuação foi intensificada, tornando a política fiscal a política econômica que mais se descolou daquela existente no período pré-crise (Araújo \& Pires 2010).

Em 2008 ocorreram desoneraçóes -setor automotivo, setores produtores de eletrodomésticos de linha branca, de material de construção- no intuito de reduzir a influência da crise mundial na demanda agregada. Seguindo neste raciocínio, no final de 2009, o setor moveleiro foi beneficiado com a isenção do Imposto sobre Produtos Industrializados. Para viabilizar o pacote de desoneraçóes fiscais sem incorrer em cortes nos gastos públicos, o governo anunciou a redução da meta de superávit primário de 4,3\% para 2,5\% do PIB para 2009. Esta variação, além de compensar a redução na receita proveniente das desoneraçóes, permitiu manter as reposiçóes salariais para o funcionalismo público, as políticas de transferência e assistência, a ampliação dos investimentos públicos e a elevação do salário mínimo (Araújo \& Pires 2010).

A mudança de atitude do governo quanto à intervenção estatal demonstrou-se também na continuidade do crescimento do número de empresas federais, ocorrido principalmente devido à expansão do Grupo Petrobras. 
Figura 3: Número de empresas estatais federais, de 1985 a 2010

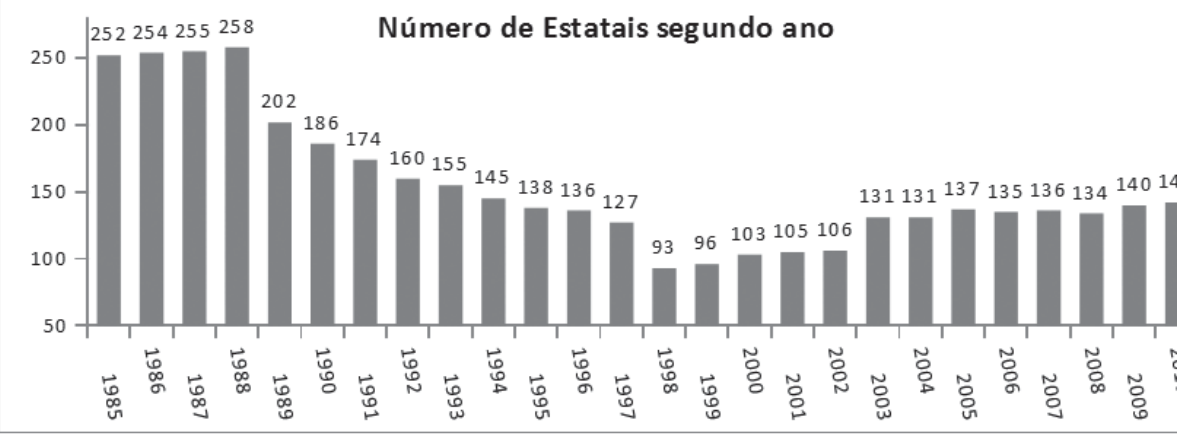

Fonte: Perfil das Empresas Estatais Federais - Departamento de Coordenação e Governança das Empresas Estatais - Ministério do Planejamento,

Orçamento e Gestão.

Novamente, o Grupo Petrobras tem uma parcela relevante deste número, mas merece destaque também o Grupo Banco do Brasil. A expansão deste banco, via incorporaçôes, só foi possível a partir de 2008 quando o governo promulgou a Medida Provisória 443. Esta medida autorizou o Banco do Brasil e a Caixa Econômica Federal a comprarem partes de instituiçóes financeiras sediadas no Brasil, através da aquisiçáo tanto de açóes como de participaçôes societárias. Para a economia, o governo sinalizou, durante a crise, que interviria ativamente no sistema financeiro, comprando ou financiando instituições financeiras privadas em dificuldade, no intuito de assegurar o funcionamento do sistema, assim como ocorrido nos Estados Unidos e na Europa. Para estes dois bancos brasileiros, a Medida Provisória permitiu que seus complexos bancários pudessem ser expandidos pela compra de partes de outras instituiçôes, possibilidade anteriormente restrita apenas às instituiçóes privadas.

As empresas estatais federais, também durante o segundo mandato de Lula, tiveram grande importância para a economia brasileira, seja com relação ao volume de investimentos -saltando de aproximadamente $1 \%$ do PIB em 2007 para pouco mais de 2\% em 2010-, seja como instrumentos de execução de políticas anticíclicas. Esmiuçando-se estes números, devese destacar o peso da categoria "infraestrutura econômica" no total do investimento público federal. No período em questão, o Grupo Petrobras respondeu por metade do investimento público federal. Após excluir a Petrobras, a infraestrutura econômica (Grupo Eletrobrás e transportes) representou 70\% dos investimentos restantes (Orair \& Gobetti 2010). 


\section{Quadro 3: Volume de investimentos de Setor Produtivo Estatal, em US\$ bilhóes, de 2003 a 2010}

\begin{tabular}{ccccccccc} 
& $\mathbf{2 0 0 3}$ & $\mathbf{2 0 0 4}$ & $\mathbf{2 0 0 5}$ & $\mathbf{2 0 0 6}$ & $\mathbf{2 0 0 7}$ & $\mathbf{2 0 0 8}$ & $\mathbf{2 0 0 9}$ & $\mathbf{2 0 1 0}$ \\
\hline US\$ bilhóes & 7,5 & 9,3 & 12,0 & 14,9 & 21,8 & 22,2 & 39,7 & 49,0 \\
$\mathbf{2 0 0 3 = 1 0 0}$ & 100 & 123,8 & 159,1 & 197,1 & 289,6 & 293,8 & 526,0 & 649,1
\end{tabular}

Fonte: Perfil das Empresas Estatais Federais - DEST/ Ministério do Planejamento, Orçamento e Gestão

Os investimentos do Grupo Petrobras, após terem permanecido relativamente estabilizados em proporção do PIB de 2002 a 2006, dobraram de 0,8\% do PIB no início de 2007 para 1,6\% em dezembro de 2009. Ou seja, o desempenho do investimento público federal no período, especialmente o destinado à infraestrutura econômica, guarda forte correlaçáo com os investimentos da holding Petrobras. A expansão dos seus investimentos coincide com o período do anúncio da descoberta de petróleo leve na camada do pré-sal em meados de 2007 e do início das exploraçôes no ano seguinte, além da retirada da Petrobras do cálculo da meta de superávit primário no ano de 2009 (Orair \& Gobetti 2010). A importância da Petrobras deve se tornar ainda maior com a redefinição do marco regulatório em que a empresa passou a ser a operadora única dos campos do pré-sal a serem licitados.

Por sua vez, o Grupo Eletrobrás, que concentra quase a totalidade dos investimentos públicos federais em energia elétrica, manteve o investimento relativamente constante de 2005 a 2007, mas também expandiu sua participação no crescimento do investimento público, passando de US\$ 1,5 bilhão investido em 2006 para aproximadamente 2,59 bilhões em 2010. Outros dados relevantes do período de 2003 a 2010, quanto ao SPE, dizem respeito ao: 1) volume de investimentos, que cresceu $374 \%$; 2) o lucro, que aumentou $294 \%$ e; 3 ) o total do ativo, que cresceu $225 \%$.

Além da importância destes grandes investimentos das empresas estatais produtivas para a execução de políticas anticíclicas, deve-se ressaltar o papel das empresas estatais financeiras, tanto no PAC como no combate à crise econômica de 2008. O estímulo ao crédito e ao financiamento de longo prazo, um dos módulos do programa de aceleração, teve grande parte de suas açôes viabilizadas através da ação da Caixa Econômica Federal e do BNDES. Estes bancos reduziram os custos para a obtenção de empréstimos, especialmente nas áreas de energia (geração, transmissão e distribuição), logística (ferrovias, rodovias, aeroportos, portos e terminais) e desenvolvimento urbano (transporte urbano integrado e saneamento 
ambiental). Enquanto diversas medidas de estímulo do Banco Central do Brasil aos bancos privados não surtiam efeito, os principais bancos públicos (Banco do Brasil, Caixa Econômica Federal e BNDES) foram chamados a suprir o mercado de crédito brasileiro, de modo a se tentar compensar a contraçáo da oferta de crédito dos bancos privados (Araujo \& Pires 2010).

O crescimento das empresas também pode ser visualizado na evolução do quadro de pessoal próprio. Segundo os dados fornecidos pelo DEST, entre 2003 e 2010, o número de funcionários próprios do SPE cresceu aproximadamente $25 \%$, enquanto o número do setor financeiro cresceu em torno de $38 \%$. No entanto, não são contabilizados nesta publicação os funcionários terceirizados, que possuem participaçóes significativas nos quadros e, em muitos casos, superam o quantitativo de pessoal próprio. Por exemplo, o Grupo Petrobras, que contava com 48.700 empregados próprios e 123.200 terceirizados em 2003, passou a empregar 80.500 funcionários próprios e 291.600 terceirizados em 2010. A evolução foi de, respectivamente, de $65,3 \%$ e $136,7 \%$, o que pode indicar que o crescimento das empresas estatais federais pode ser ainda mais significativo, caso sejam considerados também o número de contratados.

\section{CONCLUSÁO}

A atuação das empresas estatais brasileiras, após 1930, sempre foi tema de grande importância nas discussóes acerca da intervenção estatal na economia. O papel destas organizaçóes (ou o papel que lhes atribuíam) variou de acordo com as ideologias predominantes, no governo ou no cenário internacional, influenciando diretamente os movimentos de expansão ou redução da estatização da economia. Em ambos os casos, as motivações para esses processos combinavam argumentos macroeconômicos -interferências no desempenho de setores econômicos ou no equilíbrio fiscal do Estadocom informações microeconômicas - eficiência produtiva, flexibilidade, custos de mão de obra etc.

Como instrumentos de intervenção estatal, as empresas do SPE executaram diversas funçóes. Na década de 1940, estas organizaçóes atuaram no objetivo de suprir as necessidades de insumos básicos para a produção, em relativa escassez devido à Segunda Guerra Mundial. Neste mesmo período, o governo passou a atuar diretamente no processo de substituição de importaçóes nos setores onde a iniciativa privada náo era suficiente e também por julgar oportuno desenvolver setores econômicos estratégicos e, mais uma vez, as empresas estatais tiveram grande participação no processo. Durante o período da expansão do SPE, vigorou o pensamento de que a industrialização seria a principal forma de se alcançar o desenvolvimento, cabendo ao Estado fornecer a infraestrutura 
física e financeira necessária para este processo. Como eram demandados grandes e coordenados investimentos para a manutençáo e ampliação da infraestrutura física, o Estado atuou nessas frentes instalando ou ampliando as empresas estatais de serviços públicos e de apoio financeiro. Foram criadas nesta década empresas siderúrgicas, redes ferroviárias, hidrelétricas e distribuidoras de energia, petrolíferas, bancos de desenvolvimento, holdings de telecomunicaçóes etc. Esta alternativa foi adotada porque o capital nacional se via insuficiente e o estrangeiro dividia seu interesse entre vários países que tinham começado os seus processos de desenvolvimento sobre bases semelhantes.

Na década de 1980, apesar de algumas vozes defenderem a desestatização como forma de reduzir os gastos públicos, as açóes relacionadas à alienação de estatais não eram motivadas, principalmente, pela reorientação da atuação estatal em favor do mercado. Muitas privatizações foram realizadas por decisão do BNDES, como forma de reciclar seus recursos investidos. Ademais, as outras desestatizaçóes tiveram o objetivo de frear o ímpeto de crescimento desordenado das estatais ocorrido na década anterior. No entanto, apesar destes processos, não alcançaram grande êxito, subsidiariamente colaboraram para dar publicidade ao tema.

Já durante a década de 1990, ápice da desestatização no Brasil, o SPE foi severamente criticado pela sua "natural" ineficiência e falta de flexibilidade, sendo considerado pelos governantes um fardo ao erário. Tendo como referência as orientaçóes neoliberais, a existência das empresas estatais era considerada prejudicial ao desenvolvimento econômico, que deveria ser maximizado pelas livres forças do mercado. $\mathrm{O}$ processo de privatizaçáo então se intensificou, objetivando principalmente o ajuste fiscal, mas não obteve os resultados esperados. Deve-se ressaltar que náo se pode criticar o processo de privatizaçáo isoladamente, já que uma série de fatores impossibilitou o sucesso desta medida: a equivocada utilização das moedas de privatização, os erros de cálculo do valor das empresas, a grande participação do Estado como financiador de suas próprias alienaçóes etc.

A retomada da intervenção estatal na economia brasileira teve grande contribuição das empresas estatais. Não somente nos anos iniciais do governo Lula, mas principalmente durante a retração da economia mundial, ocorrida a partir de 2008, o SPE se destacou ao realizar grandes investimentos capazes de impulsionar o desenvolvimento do país, assim como de manter a economia aquecida enquanto os agentes privados se recolhiam - o que agravaria esta crise. Quanto ao ajuste fiscal do erário, as contribuiçóes recentes do SPE demonstram que as críticas incondicionais dos neoliberais à intervenção estatal e, mais especificamente, sobre as empresas estatais, não podem ser consideradas legítimas. 
A propriedade pública de uma empresa não necessariamente é uma fonte de ineficiência, como argumentado por alguns defensores da privatizaçáo. Certamente, a utilização destas organizaçóes para a execuçáo de políticas públicas interfere no seu desempenho, porém, deve-se sempre ter em mente que uma empresa, qualquer que seja, existe para remunerar os seus proprietários. Logo, como a propriedade destas empresas é pública, os resultados financeiros, analisados isoladamente, não devem ser parâmetro de avaliação já que o Estado deveria funcionar, entre outras coisas, para maximizar o bem estar da população, fazendo com que a execução de políticas públicas, potencializada pela existência das empresas estatais, tenha prioridade em relação aos resultados financeiros. Deve-se também respeitar a natureza do negócio operado pela estatal e sua própria viabilidade. Mas, como conciliar as demandas depositadas na empresa pública, como conciliar sua natureza estatal com sua natureza empresarial? É recomendável que a sustentabilidade microeconômica não seja sacrificada para que as políticas públicas tenham uma maior efetividade, ainda mais se a interferência governamental se configurar como uma grave ameaça à existência da empresa. Portanto, sáo potencialmente produtivas as discussôes acerca dos níveis de autonomia das empresas públicas.

O histórico apresentado ainda elucida alguns riscos envolvidos nas mudanças ideológicas dos governos. Uma empresa pública, uma vez privatizada, dificilmente retornará a ser propriedade pública (ainda mais se ocupar um setor rentável), enquanto que uma estatal, independente do tempo de existência, lucratividade ou papel econômico, pode ser alienada, sem o devido debate, caso uma corrente liberal assuma o poder. Porém, deve-se ter em mente que, ao mesmo tempo em que são instrumentos para a intervenção estatal, estas organizaçóes sáo empresas e devem manterse sustentáveis e competitivas, sendo mantidas enquanto oferecerem os retornos desejado a um custo, para o Estado ou para a sociedade, satisfatório.

Quanto à continuidade do crescimento do investimento público e de expansão do SPE, o atual governo de Dilma Roussef -ministra-chefe da casa civil durante o segundo mandato de Lula- segue a tendência de reforço da intervenção estatal, principalmente através do PAC 2, programa este que inicialmente previa um investimento público no total de US\$ 573,16 bilhões até 2014. Também foi continuada a expansão das concessões de serviços públicos, em especial os de infraestrutura e as Parceiras PúblicoPrivadas. Portanto, no Brasil, o governo segue combinando um modelo de intervenção direta estatal com a expansão e consolidação da função regulatória do Estado.

Sobre a pesquisa realizada, cabe destacar a dificuldade em encontrar diversos dados relativos às empresas estatais antes da década de 1980. 
Foram tomados como referências alguns relatórios e trabalhos sobre o tema, de onde foi "garimpada" uma diversidade de informaçóes nem sempre alinhadas. Descobrir o número de empresas estatais federais e estaduais, a data de criação, seus registros contábeis, entre outras informaçóes, são açôes que demandarão maiores esforços. 


\section{Quadro 4: Privatizaçóes ocorridas entre 1985 e 1989}

\begin{tabular}{|c|c|c|c|}
\hline Empresa & Setor & $\begin{array}{c}\text { Data da } \\
\text { Licitaçao }\end{array}$ & $\begin{array}{c}\text { Valor } \\
\text { Venda (US\$ } \\
\text { Milhóes) }\end{array}$ \\
\hline $\begin{array}{c}\text { Cia. Melhoramentos Blumenau - Grande } \\
\text { Hotel Blumenau }\end{array}$ & Turismo & Ago. 1986 & 0,42 \\
\hline Cia. Nacional de Tecidos Nova América & Têxtil & Jun. 1987 & 15,9 \\
\hline Máquinas Piratininga do Nordeste S. A. & Bens de Capital & Jul. 1987 & 1,4 \\
\hline Máquinas Piratininga S. A. & Bens de Capital & Nov. 1987 & 0,1 \\
\hline $\begin{array}{l}\text { Eng. Hidráulica e Instrumentação S. A. - } \\
\text { Engamatic }\end{array}$ & & Jan. 1987 & 3,8 \\
\hline Ferritas Magnéticas S. A. - Fermag & & Dez. 1987 & 0,9 \\
\hline Eletrosiderúrgica Bras. S. A. - Sibra & Ferro-ligas & Abr. 1988 & 47,6 \\
\hline Aracruz Celulose & Celulose & Mai. 1988 & 156,2 \\
\hline Cia. Guatapará de Celulose e Papel & Celulose e Papel & Mai. 1988 & 72,8 \\
\hline CaraÍba Metais S. A. & Cobre & Ago. 1988 & 89,7 \\
\hline Cia. Sider. De Moggi das Cruzes & Siderurgia & Set. 1988 & 4,1 \\
\hline Cimetal Siderúrgica S. A. & Siderurgia & Set. 1988 & 59 \\
\hline Cia. Brasileira de Cobre & Mineração & Abr. 1989 & 7,2 \\
\hline Cia. Brasileira de Zinco & Mineração & - & - \\
\hline Mineração Carmec & Mineração & - & - \\
\hline Cia de Celulose da Bahia & Celulose & Jul. 1989 & 14,4 \\
\hline Cia. De Fierro e Aço Vitória & Siderurgia & Jul. 1989 & 8,2 \\
\hline Usina Siderúrgica de Bahia & Siderurgia & Out. 1989 & 54,2 \\
\hline Siderúrgica N. S. de Aparecida & Siderurgia & Dez. 1987 & 12,9 \\
\hline
\end{tabular}

Subtotal $1985-1989$

548,82

Fonte: Secretaria Executiva do Conselho Federal de Desestatização/ M.F.. 


\section{Quadro 5: Empresas estatais federais privatizadas entre 1990 e 2005}

Nome Da Empresa

Usiminas Mecânica S.A.

Usinas Siderúrgicas de Minas Gerais

Companhia Eletromecânica

Mafersa S.A

Cosinor Distribuidora S.A.

Companhia Siderúrgica do Nordeste

Serviço de Navegação da Bacia do Prata

Aços Fionos Piratini S.A.

Petroflex Indústria e Comércio S.A.

Companhia Petroquímica do Suk

Álcalis do Rio Grande do Norte

Companhia Nacional de Álcalis

Companhia Siderúrgica de Tubarão

Fertilizantes Fosfatados S.A.

Goiás Fertilizantes S.A.

Forjas Acesita S.A.

Acesita Energética S.A.

Fábrica de Estruturas Metálicas

Companhia Siderúrgica Nacional

Ultrafértil S.A Indústria e Comércio de Fertilizantes

Companhia Siderúrgica Paulista

Aço de Minas Gerais S.A.

Petroquímica União S.A.

Mineração Caraíba Ltda.

Indústria Aeronáutica Neiva S.A.

Embraer Aviation International

Embraer Aircraft Corporation

Empresa Brasileira de Aeronáutica S.A.

Espírito Santo Centrais Elétricas

Light Serviços de Eletricidade S.A.

Companhia do Vale do Rio Doce (e 13 subsidiárias)

Banco Meridional do Brasil S.A (e cinco subsidiárias)

Sistema Telebrás (Embratel, 27 empresas de telefonia fixa e 26 de telefonia celular)

Centrais Geradoras do Sul do Brasil S.A.

Datamec S.A.

Banco do Estado de São Paulo S.A. (e cinco subsidiárias)

Banco do Estado de Goiás S.A. (e duas subsidiárias)

Banco do Estado do Amazonas S.A.
Data De Exclusáo

Out. 1991

Out. 1991

Nov. 1991

Nov. 1991

Nov. 1991

Nov. 1991

Jan. 1992

Fev. 1992

Abr. 1992

Mai. 1992

Jul. 1992

Jul. 1992

Jul. 1992

Ago. 1992

Out. 1992

Out. 1992

Out. 1992

Abr. 1993

Abr. 1993

Jun. 1993

Ago. 1993

Set. 1993

Jan. 1994

Jul. 1994

Dez.. 1994

Dez. 1994

Dez. 1994

Dez. 1994

Jul. 1995

Mai. 1997

Mai. 1997

Dez. 1997

Jul. 1998

Set. 1998

Jun. 1999

Nov. 2000

Dez. 2001

Jan. 2002 


\section{REFERÊNCIAS}

Almeida, M.H.T. de (1996). Pragmatismo Por Necessidade: as Rumos da Reforma Econômica no Brasil. Dados- Revista de Ciências Sociais, 39 (2), 213-234.

Araújo, V. L. F. C. e Pires, M. J. S. (2010). Políticas Econômicas para a Superação da Crise no Brasil: A Ação Anticíclica em Debate. En Instituto de Pesquisa Econômica Aplicada (IPEA) (Ed.), Brasil em Desenvolvimento: Estado, Planejamento e Políticas Públicas. Brasília: IPEA.

Arvate, P. R. e Maciel, V. F. (2010). Tamanho do Governo Brasileiro: Conceitos e Medidas. Revista de Administração Contemporânea, 14 (1), 1-19.

Barbosa, N. e Souza, J. A. P. (2010). A Inflexão do Governo Lula: Política Econômica, Crescimento e Distribuição de Renda. En E. Sader \& M. A. Garcia (Eds.), Brasil: entre o Passado e o Futuro. São Paulo: Fundação Perseu Abramo \& Editora Boitempo.

Baer, W., Kerstenetzky, I. e Villela, A. (1973). As Modificacôes do Papel do Estado na Economia Brasileira. Pesquisa e Planejamento Econômico, 3 (4), 883-912.

Belieiro Júnior, J. C. M. (2007). Notas de Análise Sobre a Era FHC (19942002). Revista Tópos, 1 (1), 111-122.

Banco Nacional de Desenvolvimento Econômico e Social (BNDES). (1992). Privatizaçāo. A Experiência da BNDESPAR (1987-1989). Rio de Janeiro: BNDES.

. (2002). Privatização no Brasil. Rio de Janeiro: BNDES.

Bresser Pereira, L. C. (2006). O Novo Desenvolvimentismo e a Ortodoxia Convencional. São Paulo em Perspectiva, 20 (3), 5-24.

Costa, S. et al. (1993). Privatização, neoliberalismo e o modelo de desenvolvimento brasileiro. En Fioravante, M. et al. (Eds.), A última década. Rio de Janeiro: Editora FGV.

Departamento de Coordenação e Controle das Empresas Estatais (DEST). (2008). Perfil das Empresas Estatais Federais. Ano-base 2007. Brasília: DEST. 
. (2009). Perfil das Empresas Estatais Federais. Ano-base 2008. Brasília: DEST.

. (2010). Perfil das Empresas Estatais Federais. Ano-base 2009. Brasília: DEST.

. (2011). Perfil das Empresas Estatais Federais. Ano-base 2010.

Brasília: DEST.

Fadul, E. C. (1998). Reforma do Estado e Serviços Públicos: Transformação de um Modelo ou Adaptação à uma Nova Ordem Social? En Seminário Internacional "Reestruturação e Reforma do Estado: Brasil e América Latina no processo de globalização". Anais. São Paulo: FEA/FIA/USP.

Furtado, C. (1979). Formação Econômica do Brasil. Rio de Janeiro: Cia Editora Nacional/Fundo de Cultura.

Gobetti, S. W. (2010). Estatais e Ajuste Fiscal: Uma Análise da Contribuição das Empresas Federais para o Equilíbrio Macroeconômico. Economia e Sociedade, 19 (1), 29-58.

Gurgel, C. (2003). A Gerência do Pensamento: Gestâo Contemporânea e Consciência Neoliberal. São Paulo: Cortez.

Lula (2002). Compromisso com a Soberania, o Emprego e a Segurança do Povo Brasileiro. Disponível em http://www.fpabramo.org.br/uploads/ compromissocomasoberania.pdf [15-06-2012].

Lustosa da Costa, F. e Peci, A. (1999). Desestatização como Estratégia de Reforma do Estado: Análise Preliminar da Privatização do Brasil na Nova República. Revista de Administração Pública, 33 (3), 191-205.

Morais, L. e Saad Filho, A. (2011). Da Economia Política à Política Política Econômica: O Novo-Desenvolvimentismo e o Governo Lula. Revista de Economia Politica, 31 (4), 507-527.

Moraes, L. R., A. (1997). Reestruturação dos Setores de Infraestrutura e a Definição dos Marcos Regulatórios. En Resende, F. e De Paula, T.B. (Eds.), Infraestrutura: Perspectivas e Reorganização. Brasília: IPEA.

Neves, Luciana Gomes (2006). Concessóes de rodovia: o caso da Rodovia Dutra. Dissertação (Mestrado em Economia), Universidade Federal Fluminense, Brasil. 
Orair, R. O. e Gobetti, S. W. (2010). Retomada do Investimento Público Federal no Brasil e a Política Fiscal: Em Busca de um Novo Paradigma. En Cardoso Jr., J. (Ed.), Brasil em Desenvolvimento. Brasília: IPEA.

Piccolo, M. (2010). Reformas Neoliberais no Brasil: A privatização nos Governos Collor e Fernando Henrique Cardoso. Dissertação (Mestrado em História), Universidade Federal Fluminense, Brasil.

Pinheiro, A. e Oliveira Filho de, L. (1991). Privatização no Brasil: Passado, Planos e Perspectivas. Rio de Janeiro: IPEA.

Pinheiro, A. e Giambiagi, F. (1992). As Empresas Estatais e o Programa de Privatização do Governo Collor. Rio de Janeiro: IPEA.

Pinheiro, A., Giambiagi, F. e Moreira, M. M. (2001). O Brasil na Década de 90: Uma Transição Bem-Sucedida? Rio de Janeiro: IPEA.

Rosa, L.P. e Senra, P. (1995). Participação Privada na Expansão do Setor Elétrico ou Venda de Empresas Públicas. Rio de Janeiro: COPPE/UFRJ.

Rigolon, F. e Piccinini, M. (1997). O Investimento em Infraestrutura e a Retomada do Crescimento Sustentado. Rio de Janeiro: BNDES.

Ruckert, I. (1981). Alguns Aspectos das Empresas Estatais no Brasil. Ensaios FEE, 2 (1), 75-93.

Saravia, E. (2004). Estado e Empresas Estatais. Criação e Crescimento. O Papel das Empresas Estatais como Instrumento de Politica Pública. Brasília: MPOG.

Tenório, F. G. (1997). O Estado Empresarial Brasileiro - Notas HistóricoIdeológicas. Rio de Janeiro: Editoria FGV.

Velasco, L. Jr. (1997). A Economia Politica das Politicas Públicas: Fatores que Favoreceram as Privatizaçôes no Período 1985/1994. Rio de Janeiro: BNDES.

$$
\text { Recibido: 31-08-2012 }
$$

Aceptación de la versión final: 05-04-2013 